\title{
A rapid review of measures to support people in isolation or quarantine during the Covid-19 pandemic and the effectiveness of such measures
}

\author{
Karen Cardwell ${ }^{1,2}$ (0) | Sinéad M. O'Neill ${ }^{1}$ | Barrie Tyner $^{1}$ | Natasha Broderick $^{1}$ | \\ Kirsty O'Brien $^{1}$ | Susan M. Smith ${ }^{2}$ | Patricia Harrington ${ }^{1}$ | Mairin Ryan ${ }^{1,3}$ | \\ Michelle O'Neill ${ }^{1}$
}

${ }^{1}$ Health Information and Quality Authority, Dublin 7, Ireland

${ }^{2}$ Department of General Practice, Royal College of Surgeons in Ireland, Dublin 2, Ireland

${ }^{3}$ Department of Pharmacology and Therapeutics, Trinity College Dublin, Trinity Health Sciences, Dublin 8, Ireland

\section{Correspondence}

Karen Cardwell, Health Information and Quality Authority, Smithfield, Dublin 7, Ireland.

Email: kcardwell@hiqa.ie

Funding information

Health Research Board, Grant/Award Number: HRB-CICER-2016-1871

\section{Summary}

This rapid review aimed to identify measures available to support those in isolation or quarantine during the coronavirus disease 2019 (Covid-19) pandemic, and determine their effectiveness in improving adherence to these recommendations and or reducing transmission. The rapid review consisted of two elements, the first was a review of guidance published by national and international agencies relating to measures to support those in isolation (due to case status) or quarantine (due to close contact status) during the Covid-19 pandemic. Five categories of support measures were identified in the international guidance, they were: Psychological, addiction and safety supports, Essential supplies, Financial aid, Information provision and Enforcement. The second element was a rapid literature review of the effectiveness of measures used to support individuals in isolation or quarantine during any pandemic or epidemic setting, due to respiratory pathogens. A systematic search of published peer-reviewed articles and nonpeer-reviewed pre-prints was undertaken from 1 January 2000 to 26 January 2021. Two Australian publications met the inclusion criteria, both based on data from a survey undertaken during the $2009 \mathrm{H} 1 \mathrm{~N} 1$ pandemic. The first reported that $55 \%$ of households were fully compliant with quarantine recommendations, and that there was increased compliance reported in households that understood what they were meant to do compared with those who reported that they did not (odds ratio [OR]: $2.27,95 \%$ confidence interval $[\mathrm{Cl}]: 1.35-3.80)$. The second reported that access to paid sick and or carer's leave did not predict compliance with quarantine recommendations (OR: $2.07,95 \% \mathrm{Cl}$ : 0.82-5.23). Neither reported on reduction in transmission.

Abbreviations: Covid-19, coronavirus disease 2019; ECDC, European Centre for Disease Prevention and Control; MERS, Middle East respiratory syndrome; PPE, personal protective equipment; SARS-CoV-2, severe acute respiratory syndrome coronavirus 2; WHO, World Health Organisation.

Mairin Ryan and Michelle O'Neill are co-senior authors.

This is an open access article under the terms of the Creative Commons Attribution-NonCommercial-NoDerivs License, which permits use and distribution in any medium, provided the original work is properly cited, the use is non-commercial and no modifications or adaptations are made.

(c) 2021 The Authors. Reviews in Medical Virology published by John Wiley \& Sons Ltd. 


\section{1 | BACKGROUND}

On 11 March 2020, the World Health Organisation (WHO) declared the coronavirus disease 2019 (Covid-19) outbreak a global pandemic As of 16 March 2021, there have been almost 120 million cases and over 2.5 million deaths from laboratory-confirmed cases of Covid-19 worldwide. ${ }^{1}$ In the context of the overall public health response to Covid-19, effective management of cases and their contacts is key to reducing the spread of Covid-19. In regard to cases, that is, those with confirmed or suspected Covid-19 infection, isolation is the term used to describe their separation from those who are not infected. Quarantine is the term used to describe separation of those exposed or potentially exposed to severe acute respiratory syndrome coronavirus 2 (SARS-CoV-2) from others, as a precautionary measure because they may have the disease. ${ }^{2,3}$ Measures to support individuals in isolation and quarantine should be considered to improve compliance with the recommendations. ${ }^{4}$ As such, the aim of this rapid review was to (1) identify the measures being taken internationally to support compliance with isolation and quarantine recommendations during the Covid-19 pandemic (a review of international guidance) and (2) to determine the effectiveness of such measures during pandemics or epidemics involving respiratory pathogens (a review of primary research studies) on compliance and reduction in spread of infection.

\section{METHODS}

A detailed summary of the methods used in this rapid review is provided in the protocol, ${ }^{5}$ which is in accordance with Cochrane rapid review methodology guidance. ${ }^{6}$

In short, official national and international agency websites from a predefined list were searched for measures implemented to support those in isolation or quarantine during the Covid-19 pandemic. Supports identified were then categorised by theme. Following a scoping exercise, it was evident that there was a lack of evidence relating to the effectiveness of measures implemented to support those in isolation or quarantine during the Covid-19 pandemic. Therefore, evidence of the effectiveness of measures implemented to support those in isolation or quarantine relating to other respiratory pathogens (e.g., SARS-CoV and Middle East respiratory syndrome [MERS]) from an epidemic or pandemic situation from 2000 to 2021 were included. A systematic search of published peer-reviewed articles and nonpeer-reviewed preprints was undertaken from 1 January 2000 up to 26 January 2021; no language restrictions were applied. All potentially eligible papers were exported to Covidence (www.covidence.org) and titles/abstracts and full texts were single screened for relevance based on the inclusion/exclusion criteria outlined in the protocol. Data extraction and quality appraisal of included studies was completed by a single reviewer and checked by a second reviewer; the Joanna Briggs Institute checklist for analytical cross sectional studies was used for quality appraisal of included studies. $^{7}$

\section{RESULTS}

\section{1 | International review}

In total, guidance from the European Centre for Disease Prevention and Control (ECDC), WHO and official national and international agency and or government websites from 19 countries, relating to measures to support those in isolation or quarantine, were included in this review. The findings were summarised into five main categories of support measures. Table 1 provides a summary of the measures found to support individuals who are in isolation or quarantine during the Covid-19 pandemic.

\section{2 | Psychological, addiction and safety support measures}

Psychological support measures were identified in 18 of the 19 countries reviewed; this included mental health support, addiction support as well as support for victims of violence (domestic and or child abuse). This support is available to those isolating, quarantining, or those affected by restrictions in general. Available support was varied and included information leaflets, helplines, online appointments or video conferences with counsellors or psychologists. The information on websites did not specify if organisations were government funded, whether there was a fee for those using the service, nor did they specify which organisations existed before the Covid-19 pandemic.

In line with recommendations from the $\mathrm{ECDC}^{8}$ and the $\mathrm{WHO},{ }^{9,10}$ agency and or government websites for Austria, ${ }^{11}$ Australia, ${ }^{12-15}$ Belgium, ${ }^{16}$ Canada, ${ }^{17,18}$ Demark, ${ }^{19}$ England, ${ }^{20,21}$ Finland, ${ }^{22-25}$ France, ${ }^{26,27}$ the Netherlands, ${ }^{28,29}$ New Zealand, ${ }^{30,31}$ Norway, ${ }^{32}$ Scotland ${ }^{33}$ and Switzerland ${ }^{34}$ have listed resources for mental health support, addiction support and or support for victims of violence. Typically, the support offered is in the form of online information portals and information sheets, as well as helplines and online counselling services. Official agency and or government websites for Wales ${ }^{35}$ and Singapore ${ }^{36}$ have listed resources for mental health and victims of violence. Ireland ${ }^{37,38}$ has resources for mental health support and addiction support, and Iceland ${ }^{39}$ and Northern Ireland ${ }^{40}$ listed resources for mental health support (see Table 1). 


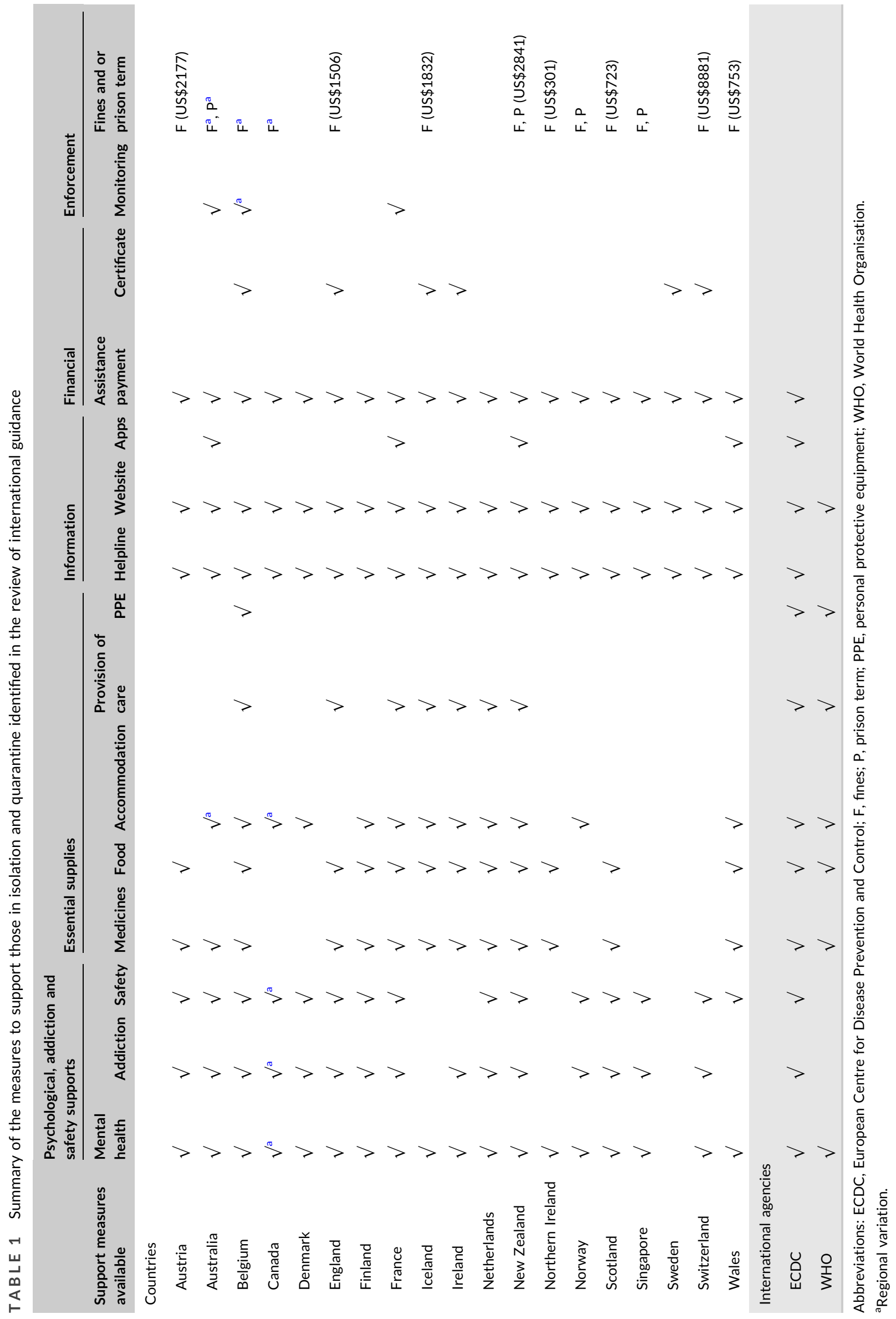


It should be noted that while official national and international agency and or government websites may not have listed specific support measures available during the Covid-19 pandemic, this does not mean that support is not available. For example, in Ireland, support for victims of domestic abuse continues to be made available through organisations such as Safe Ireland which existed pre-Covid19. ${ }^{41}$

\subsection{Essential needs support measures}

Guidance from the $\mathrm{ECDC}^{8,42}$ and $\mathrm{WHO}^{9}$ highlights the importance of ensuring that individuals who are isolating or quarantining have access to daily essential needs. This encompasses access to medicines, food, accommodation, provision of care (including healthcare and childcare) and personal protective equipment (PPE); the ECDC recommend that medical face masks are used by everyone in households where there are people with symptoms of Covid-19 or confirmed Covid-19. ${ }^{42}$ Information on support in relation to an individual's essential needs was available in 16 of the 19 countries reviewed. 12,15,19,20,28,31,35,40,43-56 The level of support identified ranged from extremely comprehensive support covering all essential needs (i.e., medicines, food, accommodation, provision of care and PPE) to covering fewer of these needs; see Table 1. Specific supports may not always be identified on government websites, but that does not necessarily mean they are not available. For example, in Singapore isolation of cases and quarantine of close contacts must be completed in purpose-built isolation centres where all essential needs, including psychological support, are met. ${ }^{57}$

\section{4 | Information}

The WHO recommend that national communication strategies equip the public with comprehensive information about Covid-19. ${ }^{58}$ All countries reviewed provided some form of information support for those isolating or quarantining. ${ }^{11,12,14-19,21,24,27,28,30,33,35,36,38,54,59-72}$ In addition to specific information to support those required to isolate or quarantine, information sources typically provided comprehensive information regarding a wide range of Covid-19 related issues. The most common form of information support available could be accessed via helplines or websites; some countries (Australia, ${ }^{12,15}$ France, ${ }^{68}$ New Zealand ${ }^{30}$ and Wales ${ }^{35}$ ) also provided information through mobile phone applications (see Table 1).

\section{5 | Financial support measures}

All countries reviewed provided details of financial support available to those who are isolating or quarantining. ${ }^{13,28,36,40,45,50,51,65,73-90}$ Some countries provide individuals with a certificate informing them of their need to isolate or quarantine; which enabled them to access available financial supports. The payments varied between countries and were typically a fixed amount rather than a percentage of the individual's salary (see Table 1).

\subsection{Enforcement}

Of the 19 countries reviewed, only Australia, ${ }^{55}$ Belgium $^{91}$ and France ${ }^{89}$ reported monitoring those who should be isolating or quarantining (subject to regional variation). Austria, ${ }^{46}$ Australia, ${ }^{14,55,92-94}$ Belgium, ${ }^{86,95}$ Canada, ${ }^{51}$ England, ${ }^{21}$ Iceland, ${ }^{96}$ New Zealand, ${ }^{97}$ Northern Ireland, ${ }^{98}$ Norway, ${ }^{99}$ Scotland, ${ }^{100}$ Singapore, ${ }^{101}$ Switzerland ${ }^{102}$ and Wales ${ }^{103}$ report the use of fines and or prison terms (Australia, ${ }^{14,93,94}$ New Zealand, ${ }^{97}$ Norway ${ }^{99}$ and Singapore ${ }^{101}$ ) for noncompliance to the regulations. The fine imposed varies by country and in some cases by state or province (namely, Australia, Belgium and Canada) (see Table 1).

\section{7 $\quad$ Rapid literature review}

Across the databases searched, the collective search up until 20 January 2021 resulted in 1343 citations; the search strategy included terms for other respiratory pathogens (e.g., SARS-CoV and MERS) during an epidemic or pandemic situation from 2000 to 2021. Following removal of duplicates 1301 citations were screened for relevance, with 158 full-texts assessed for eligibility and 156 subsequently excluded. See Figure 1 for a PRISMA flow diagram of the studies included in this review. Accordingly, after full review of the inclusion criteria, two publications were identified for inclusion based on one study.

Both publications, by Kavanagh et al., ${ }^{104,105}$ were conducted in the school setting in Australia and used the same dataset, but reported on different measures implemented to support isolation and quarantine. These publications reported data from one study with each publication reporting on different measures of support. Survey data were collected in November and December 2009. The data collected related to quarantine recommendations implemented from 22 May 2009 to 2 June 2009 during the 2009 H1N1 pandemic. Voluntary home quarantine of cases and close contacts was the main intervention used to limit transmission of (H1N1)pdm09 flu virus during the initial response to the outbreak of the disease in Australia. The trigger for closure of mainstream schools was two or more confirmed cases in separate classes. ${ }^{104,105}$

The findings published in $2011,{ }^{105}$ reported on compliance with restrictive measures as a result of information on quarantine having been provided. Data were included from 297 families; $49 \%$ of respondents' children were under 12 years old, $54 \%$ of respondents were male and $17 \%$ had a confirmed case of (H1N1)pdm09 flu virus in their household. ${ }^{105}$ Overall, 90\% (166/297) of participants understood what they were meant to do during the quarantine period. This proportion was significantly higher in households with cases than in households with contacts only $(98 \%, 95 \%$ confidence interval [Cl]: $93 \%-99 \%$ vs. $88 \%$, 95\% Cl: $84 \%-91 \%, p<0.001)$. Nearly $90 \%$ of 


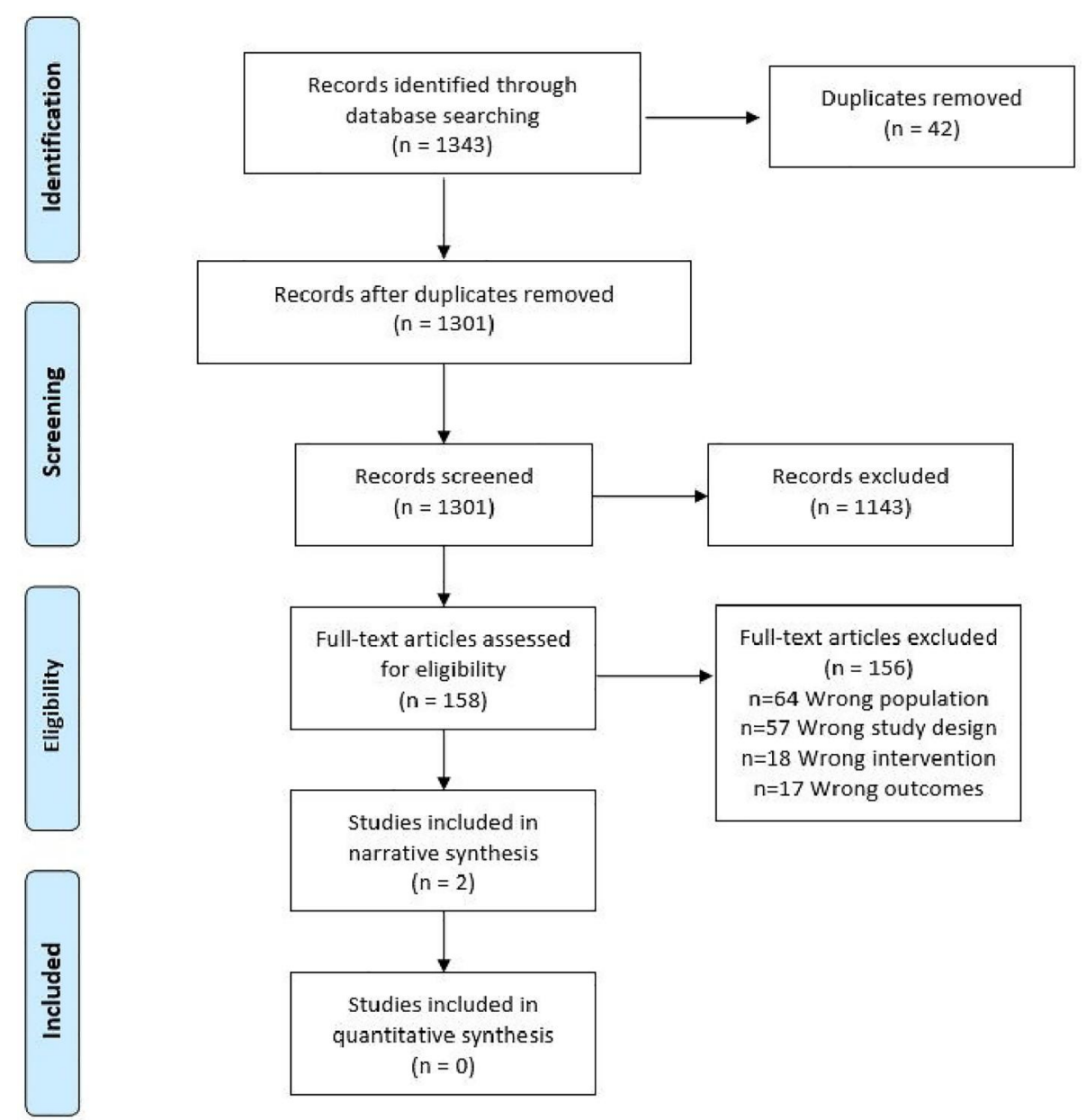

FIGURE 1 PRISMA flow diagram of included publications

parents received information about quarantine from the school and $63 \%$ obtained information from the health department. The next most common information source was the media (44\%). Overall, most families used multiple sources of information; only one household reported that they did not use any sources. Regarding the source of information used, $24 \%$ used one source, $32 \%$ used two, and $44 \%$ used three or more sources of information. ${ }^{105}$ Approximately two-thirds of participants reported that they found the information from the health department, schools and health service providers useful or extremely useful, whereas only $38 \%$ gave media sources this rating. Full compliance with quarantine recommendations within their household was reported by $55 \%$ of all participants. Compliance was higher in the households that reported understanding what they were meant to do during the quarantine period compared with those who did not (55\% vs. $35 \%$, odds ratio [OR] $2.27,95 \% \mathrm{Cl}: 1.35-$ 3.80). ${ }^{105}$

The findings published in $2012,{ }^{104}$ reported on the compliance with restrictive measures as a result of access to paid sick leave or paid leave to look after quarantined children. Data from 133 households were used, all of whom included a resident parent that was employed during the quarantine period. At the time of data collection, $6 \%$ of respondents had a confirmed case of (H1N1)pdm09 flu virus in their household. A larger proportion of households with access to leave had a parent who took time off work to care for a child (58\% [47/81] vs. 42\% [22/52]). Half of all households were fully compliant with quarantine recommendations. Compared to households without access to sick leave or leave to look after quarantined children, households with access to leave appeared more likely to have all quarantined members stay at home for most of the time on all days during the quarantine period (88\% compared with 75\%) (OR: 2.07, 95\% Cl: 0.82-5.23, $p=0.12$ after adjustment for parental structure and parental education). ${ }^{104}$ In terms of the relationship between taking time off and quarantine compliance (independent of access to leave), quarantined members of households in which a parent took time off work were less likely to make trips to populated public spaces during the quarantine period ( $97 \%$ vs. $84 \%$ ) and these households were more likely to have all quarantined members stay at home for most of the time on all days during the quarantine period (88\% vs. $77 \%$ ). ${ }^{104}$ After adjustment for parental education and parental structure of households, taking time off work was associated with over double the odds of staying at home on all days (OR: $2.47,95 \% \mathrm{Cl}: 1.17-5.22, p=0.02$ ) and seven times the odds of not making trips outside the home (OR: 7.20 , $95 \% \mathrm{Cl}: 1.42-$ $36.51, p=0.02$ ). Taking time off work was not, however, associated with full compliance. ${ }^{104}$ 


\section{8 | Quality appraisal}

The study included in this review consisted of two publications reporting on different measures of support. The publications were deemed to be of very low quality and a number of issues were identified. The study ${ }^{104,105}$ was an observational cross-sectional study. Therefore, it is particularly vulnerable to biases (e.g., recall bias) and may not incorporate important confounding factors. In the 2011 publication, ${ }^{105}$ it was unclear whether the exposure (i.e., information on quarantine) was measured in a valid and reliable way. In the 2012 publication, ${ }^{104}$ no demographic data were presented for the study population. In both publications, ${ }^{104,105}$ it was unclear if outcomes (i.e., compliance with recommendations and reduction in spread of infection) were measured in a valid and reliable way.

\section{4 | DISCUSSION}

\subsection{Overview of international review}

This rapid review comprised two parts, the first was a review of international guidance which identified five broad categories of measures that are available to support those who are in isolation or quarantine. The ECDC and WHO identify a range of supports necessary to improve compliance with isolation and quarantine. While all countries reviewed provide some degree of support, these appear to differ in intensity. For example, some countries primarily target their supports at vulnerable individuals or those who are ordinarily dependent on state-aid. In general, support is provided either by a mixture of state agencies or by charitable bodies who have been provided with state support to fund their activities; many countries are leveraging off existing support services rather than establishing de novo services for Covid-19. Most services appear reactive, with the requirement for the individual to seek assistance, but some are proactively targeting individuals known to be medically or financially vulnerable. In addition to using supportive measures to encourage compliance to isolation and quarantine recommendations, punitive measures were also identified; these included monitoring of cases and contacts as well as fines and or prison terms for breaching the regulations.

As noted, all 19 of the countries included in this review provided financial assistance and 12 of the 19 countries provided suitable accommodation. The need to work for financial reasons has been identified as one of the most widely cited reasons in the research as to why people do not isolate appropriately, particularly in those of lower socioeconomic status. Lack of suitable accommodation and essential supplies has also been identified as a common barrier for people to self-isolate. ${ }^{106}$ While many countries have reduced the length of isolation required for cases in an effort to improve compliance, the evidence of improved compliance is mixed. In a review by Webster et al., ${ }^{107}$ the authors reported that reduced length of isolation or quarantine did not affect compliance with recommendations during the H1N1 pandemic in Australia. Evidence of the effectiveness of monitoring compliance with the regulations and penalties for noncompliance is mixed and largely dependent on the culture within which the measures are implemented. ${ }^{106}$ In general, individualism and independence is encouraged in Western culture, whereas in Asian cultures there is greater emphasis on collectiveness and interdependency. ${ }^{108}$ Furthermore, research has highlighted differences in terms of more strict social norms in countries like China, Japan and Singapore compared with Italy and the United States, whereby there is punishment for breaking regulations. ${ }^{109}$ As such, individuals may be more compliant compared with those in 'looser', western cultures. $^{108}$

Overview of evidence summary on the effectiveness of measures to support isolation or quarantine on compliance and reduction in spread of infection.

The second element of this rapid review was a review of literature on the effectiveness of measures to support those in isolation or quarantine, that is, increased compliance with recommendations and reduced spread of infection. The lack of evidence identified in this review was echoed in a report by the National Academies of Sciences, Engineering, and Medicine published in July 2020. It included a mixed-methods review of implementing quarantine (including isolation and or quarantine) to reduce or stop the spread of a contagious disease. ${ }^{110}$ The authors used quantitative evidence from research studies to determine the effectiveness of strategies to improve compliance with quarantine recommendations. ${ }^{110}$ The evidence predated the Covid-19 pandemic, and included other infectious diseases, such as SARS-CoV, MERS, Ebola, smallpox and measles and concluded that compliance with quarantine recommendations can vary by culture, disease and socioeconomic status. Furthermore, identified evidence provided low certainty evidence that such strategies (e.g., risk communication and messaging and access to employment leave) improve compliance with quarantine recommendations. ${ }^{110}$

\subsection{Additional considerations}

Others reviews identified did not report on the effectiveness (i.e., compliance with regulations and reduction in spread of infection) of measures to support those in isolation or quarantine. However, they provided an insight into the measures that study participants perceived to be of support during isolation and quarantine. DiGiovanni et al. ${ }^{111}$ conducted a mixture of structured and unstructured interviews as well as focus groups with over 1700 residents of the Greater Toronto Area who were affected by the public health measures implemented to control the SARS pandemic in 2003; participants included the general public, government officials, healthcare workers and students. The authors identified a number of factors that impeded compliance with the recommendations. The overriding theme was fear of loss of income, especially in those who were not convinced that their quarantine was necessary. The absence of monitoring (that authorities claimed would be enforced) invited noncompliance, as did lack of support with obtaining essential items 
(e.g., food). Inconsistency in information provision or in the application of recommendations between jurisdictions created confusion and lack of confidence even among those who intended to comply. Stress and stigma associated with quarantine was also cited as a reason for noncompliance. ${ }^{111}$ Similarly, in a review by Webster et al., ${ }^{107}$ published in March 2020, the most common factors that were associated with increased compliance with isolation recommendations during an infectious disease outbreak were related to improved knowledge about the disease and purpose and benefit of isolation, as well as the provision of adequate essential supplies and financial support. ${ }^{107}$

The psychological impact of imposed isolation is well cited in the research literature. In a review by Brooks et al., ${ }^{112}$ the negative psychological effects of isolation included postraumatic stress symptoms, confusion and anger. Such effects were compounded by extended durations of isolation, fears of infection, frustration, boredom, inadequate supplies, lack of information, financial pressures and stigma. ${ }^{112}$ The authors concluded that if isolation is indicated, the duration of isolation should not be any longer than necessary, and that adequate information and supplies should be provided. ${ }^{112}$ In the same way that the provision of adequate, factual information is important in empowering individuals to adhere to isolation recommendations, warning people about misinformation and providing them with counterarguments against false information and conspiracy theories is equally important. ${ }^{113}$ As highlighted previously, evidence on the effectiveness of penalties for lack of compliance with the regulations is lacking. Instead, people should be made aware of the practical and emotional support that is available to them throughout this time and the benefits of isolation for themselves and society as a whole should be outlined. ${ }^{114}$ As such, promoting solidarity and altruism through community engagement, outreach initiatives and collaboration on communication strategies is vital in ensuring compliance. ${ }^{115}$

In addition to the provision of measures to support those in isolation (e.g., adequate essential supplies and financial support) there is a need to effectively communicate the existence of such support measures to help individuals feel prepared should they need to isolate. Some countries provide this information through Web applications (apps) that utilise conditional logic. Such apps enable people to identify the social and financial supports that are both available and applicable to their specific situation. Research shows that individuals cope better with changes in lifestyle when they plan for said changes; this has also been shown to enable better compliance with public health guidance. ${ }^{116}$ In a study conducted in Ireland researchers hypothesised that, individuals would have increased confidence in their ability to isolate if they used an online tool (or decision aids) to help them make a plan and develop a routine for isolation. ${ }^{117}$ The study, which was uncontrolled, conducted in April 2020 ( $n=500$ individuals), tested three interventions to help individuals first decide whether they need to isolate, second be confident in their ability to isolate should they need to and third manage a household in which an individual needs to isolate. ${ }^{117}$ The authors reported that the behaviourally informed decision aids were associated with statistically significant, positive outcomes and can be used to support isolation during the Covid-19 pandemic. As such, the findings from the study have been incorporated into social media campaigns in Ireland. ${ }^{117}$

In July 2020, a follow-up study was conducted in 1000 individuals living in Ireland; the aim of which was to understand an individual's willingness to isolate. ${ }^{118}$ The results showed that less than $40 \%$ of individuals with one of the main Covid-19 symptoms (fever, cough, shortness of breath, change and or loss of taste and or smell) would isolate immediately and $50 \%$ would contact their GP. ${ }^{118}$ The factors that independently increased the likelihood of isolating immediately were being female, having a degree and being an Irish national. ${ }^{118}$ In the same sample, there was a lack of awareness around how to access a Covid-19 test, and that such tests were available free of charge. ${ }^{119}$ Researchers recommended that test and trace staff should be utilised to direct individuals to available resources should they have to isolate or quarantine. Likewise, human resources departments should also be utilised to direct employees to available resources should they need to isolate or quarantine. ${ }^{119}$

This review has a number of limitations. First, although official national and international agency and or government websites were reviewed to identify measures to support those in isolation or quarantine, there is a possibility that some measures may be in place, but are not documented on the websites reviewed. Second, this review did not evaluate if there was a relationship between the range and or intensity of measures offered and the burden of disease experienced in that country. Third, this review is limited by the type of review conducted for the effectiveness element of the question (i.e., a 'rapid literature review'). This was limited by the time constraints associated with the review, and the biases considered likely to be present in the primary research studies included.

\section{5 | CONCLUSION}

This rapid review identified five categories of measures available to support individuals in isolation or quarantine. At a country level, there appears to be variation in the range and intensity of supports offered, the mechanisms by which the supports are offered, whether support is proactive or reactive, and if supports are universal or preferentially targeted at vulnerable groups.

Measures to support individuals in isolation or quarantine aim to reduce spread of infection by improving compliance with recommendations and or regulations. At the time of writing there is a paucity of evidence from primary research studies relating to the effectiveness of these measures either in increasing compliance or in reducing spread of infection. No data were identified relating to the effectiveness of measures on official national and international agency and or government websites. Data from qualitative and decision support studies report that improved knowledge about the disease and purpose of the recommendations, as well as the provision of adequate essential supplies and financial support are perceived as being of most importance by individuals, to support them in isolation 
or quarantine. In addition, signposting to available resources is key to helping individuals plan for isolation and be confident in their ability to do so effectively.

\section{ACKNOWLEDGEMENTS}

The authors would like to thank the Library and Information Services at the Health Service Executive, Ireland and acknowledge the support of the Health Technology Assessment at HIQA. This research was funded in part by the Health Research Board under grant no. HRB-CICER-2016-1871. This research has informed the work of the National Public Health Emergency Team in Ireland in its response to Covid-19.

\section{CONFLICTS OF INTERESTS}

The authors declare that there are no conflict of interests.

\section{AUTHOR CONTRIBUTIONS}

Karen Cardwell, Sinéad M. O'Neill, Barrie Tyner, Natasha Broderick and Kirsty O'Brien scoped the question, constructed the systematic search, screened titles/abstracts and full-texts and completed the data extraction and quality appraisal. Karen Cardwell wrote the manuscript. All authors reviewed and contributed to the writing of the manuscript.

\section{DATA AVAILABILITY STATEMENT}

Data sharing is not applicable to this article as no new data were created or analysed in this study.

\section{ORCID}

Karen Cardwell (D) https://orcid.org/0000-0002-5909-7439

\section{REFERENCES}

1. World Health Organisation. WHO Coronavirus Disease (COVID19) Dashboard 2021. https://covid19.who.int/. Accessed March 16, 2021.

2. Health Protection and Surveillance Centre. COVID-19 Contact Management Programme (CMP) Overview. https://www.hpsc.ie/az/respiratory/coronavirus/novelcoronavirus/guidance/contacttrac ingguidance/Leaflet\%201\%20CMP\%200verview.pdf. Accessed February 4, 2021.

3. Centers for Disease Control and Prevention. Quarantine and Isolation. https://www.cdc.gov/quarantine/index.html. Accessed February 4, 2021.

4. Health Information and Quality Authority. Duration of restricted movements following exposure to SARS-CoV-2, and the potential impact of testing. https://www.hiqa.ie/reports-and-publications/ health-technology-assessment/restriction-movements-individualsexposed-or. Accessed January 12, 2021.

5. Health Information and Quality Authority. Protocol: What measures have been taken to support people in self isolation or restriction of movements to improve compliance with and effectiveness of such measures. https://www.hiqa.ie/sites/default/ files/2021-02/Measures-to-support-self-isolation-and-ROM-proto col.pdf. Accessed January 22, 2021.

6. Garritty C, Gartlehner G, Nussbaumer-Streit B, et al. Cochrane Rapid Reviews Methods Group offers evidence-informed guidance to conduct rapid reviews. J Clin Epidemiol. 2021;130: 13-22.
7. Joanna Briggs Institute. Critical Appraisal Checklist for Analytical Cross Sectional Studies. https://jbi.global/sites/default/files/201905/JBI_Critical_Appraisal-Checklist_for_Analytical_Cross_Sectional_ Studies2017_0.pdf. Accessed February 19, 2020.

8. European Centre for Disease Prevention and Control. Guidelines for the implementation of non-pharmaceutical interventions against COVID-19. https://www.ecdc.europa.eu/sites/default/files/ documents/Medically-and-socially-vulnerable-populations-COVID-19. pdf. Accessed September 24, 2020.

9. World Health Organisation. Considerations for quarantine of contacts of COVID-19 cases 2020. https://www.who.int/ publications/i/item/considerations-for-quarantine-of-individualsin-the-context-of-containment-for-coronavirus-disease-(covid-19). Accessed August 19, 2020.

10. World Health Organisation. Policy Brief: COVID-19 and the Need for Action on Mental Health 2020. https://www.un.org/sites/ un2.un.org/files/un_policy_brief-covid_and_mental_health_final.pdf. Accessed May 13, 2020.

11. Federal Ministry of Social Affairs, Health, Care and Consumer Protection, Austria. Coronavirus - Psychological Help 2021. https:// www.sozialministerium.at/Informationen-zum-Coronavirus/Corona virus-\%E2\%80\%93-Psychologische-Hilfe.html. Accessed January 07, 2021.

12. Australian Government Department of Health. Isolation for coronavirus (COVID-19). https://www.health.gov.au/news/healthalerts/novel-coronavirus-2019-ncov-health-alert/how-to-protectyourself-and-others-from-coronavirus-covid-19/isolation-for-corona virus-covid-19. Accessed February 02, 2021.

13. Government of Australia. Pandemic Leave Disaster Payment. https://www.servicesaustralia.gov.au/individuals/services/centre link/pandemic-leave-disaster-payment. Accessed February 02, 2021.

14. State Government of New South Wales. Self-isolation rules. https:// www.nsw.gov.au/covid-19/what-you-can-and-cant-do-under-rules/ self-isolation\#mandatory-quarantine. Accessed February 02, 2021.

15. Government of Australia. Support During Covid-19. https:// www.health.gov.au/news/health-alerts/novel-coronavirus-2019ncov-health-alert/ongoing-support-during-coronavirus-covid-19. Accessed February 02, 2021.

16. Government of Belgium. Take care of yourself and your emotions. https://www.info-coronavirus.be/nl/psychosociale-hulpverlening/. Accessed February 02, 2021.

17. Government of Alberta. COVID-19 info for Albertans. https:// www.alberta.ca/coronavirus-info-for-albertans.aspx. Accessed February 02, 2021.

18. Government of Ontario. COVID-19: Support for people. www. ontario.ca/page/covid-19-support-people. Accessed February 02, 2021.

19. Danish Health Authority. Advice from hotlines and other authorities. https://www.sst.dk/da/corona/Yderligere-information/Hot lines. Accessed February 02, 2021.

20. Government of the United Kingdom. Guidance for the public on the mental health and wellbeing aspects of coronavirus (COVID-19). https://www.gov.uk/government/publications/covid-19-guidancefor-the-public-on-mental-health-and-wellbeing/guidance-for-thepublic-on-the-mental-health-and-wellbeing-aspects-of-coronaviruscovid-19. Accessed February 02, 2021.

21. Public Health England. Stay at home: guidance for households with possible or confirmed coronavirus (COVID-19) infection. https:// www.gov.uk/government/publications/covid-19-stay-at-home-guid ance/stay-at-home-guidance-for-households-with-possible-corona virus-covid-19-infection\#looking-after-your-health-and-wellbeing. Accessed February 02, 2021.

22. Finnish Institute for Health and Welfare. Reducing risk and stress. https://thl.fi/en/web/mental-health/what-s-new/mental-health-and- 
the-coronavirus-epidemic/reducing-risk-and-stress. Accessed February 02, 2021.

23. Finnish Institute for Health and Welfare. Seeking help. https://thl. fi/en/web/mental-health/what-s-new/mental-health-and-the-corona virus-epidemic/seeking-help. Accessed February 02, 2021.

24. Finnish Institute for Health and Welfare. Strengthening your coping - and that of others. https://thl.fi/en/web/mental-health/ what-s-new/mental-health-and-the-coronavirus-epidemic/strength ening-your-coping-and-that-of-others. Accessed February 02, 2021.

25. Finnish Institute for Health and Welfare. Support others. https:// thl.fi/en/web/mental-health/what-s-new/mental-health-and-thecoronavirus-epidemic/support-others. Accessed February 02, 2021.

26. Sante publique (Public Health) France. COVID-19: Taking care of your mental health during the epidemic. https://www. santepubliquefrance.fr/maladies-et-traumatismes/maladies-et-infec tions-respiratoires/infection-a-coronavirus/articles/covid-19-pren dre-soin-de-sa-sante-mentale-pendant-I-epidemie. Accessed February 02, 2021.

27. France24. Toolbox: Home quarantine and isolation. https:// covid19.public.lu/fr/toolbox/informations-quarantaine-isolement. html. Accessed February 16, 2021.

28. Government of Netherlands. Brochure - Help and support when self-quarantining (staying at home) 2020. https://www. government.nl/documents/leaflets/2020/10/23/help-and-supportwhen-self-quarantining-staying-at-home. Accessed February 02, 2021.

29. Rijksoverheid. Coronavirus and mental health care. https://www. rijksoverheid.nl/onderwerpen/coronavirus-covid-19/gezondheid-enzorg/geestelijke-gezondheidszorg-ggz. Accessed February 02, 2021.

30. Ministry of Health. New Zealand. Supporting your own mental wellbeing. https://www.health.govt.nz/our-work/diseases-and-con ditions/covid-19-novel-coronavirus/covid-19-health-advice-public/ covid-19-mental-health-and-wellbeing-resources. Accessed February 02, 2021.

31. Unite against COVID-19. If you need help with accommodation. https://covid19.govt.nz/everyday-life/life-at-home/need-help-withaccommodation/. Accessed February 16, 2021.

32. Norwegian Centre for Violence and Traumatic Stress. Coronavirus: Advice for those experiencing mental health issues. https://www.nkvts.no/english/corona-advice-on-how-to-cope-withthe-situation/coronavirus-advice-for-those-experiencing-mentalhealth-issues/. Accessed February 02, 2021.

33. Scottish Government's Resilience Division. Ready Scotland. https://ready.scot/coronavirus/get-help. Accessed February 02, 2021.

34. Federal Office of Public Health, Sweden. COVID-19: Instructions on quarantine. https://www.bag.admin.ch/bag/en/home/krankheiten/ ausbrueche-epidemien-pandemien/aktuelle-ausbrueche-epidemien/ novel-cov/isolation-und-quarantaene.html. Accessed February 02, 2021.

35. Welsh Government. Find support if you're affected by coronavirus. https://gov.wales/find-support-affected-coronavirus. Accessed February 02, 2021.

36. Government of Singapore. Official COVID-19 sources 2020. https://www.gov.sg/article/covid-19-resources. Accessed February 02, 2021.

37. Health Service Executive, Ireland. Keeping well in self-isolation 2020. https://www2.hse.ie/conditions/coronavirus/self-isolation/ keeping-well.html. Accessed February 02, 2021.

38. Government of Ireland. Symptoms of COVID-19 and how to protect yourself 2021. https://www.gov.ie/en/publication/472f64covid-19-coronavirus-guidance-and-advice/. Accessed February $02,2021$.
39. Directorate of Health, Iceland. Instructions for persons under home-based quarantine 2020. https://www.landlaeknir.is/umembaettid/greinar/grein/item43539/Instructions-for-persons-underhome-based-quarantine. Accessed February 02, 2021.

40. NI Direct. Coronavirus (COVID-19) and Benefits. https://www. nidirect.gov.uk/articles/coronavirus-covid-19-and-benefits. Accessed February 02, 2021.

41. Safe Ireland. Important information relating to domestic abuse and COVID-19. https://www.safeireland.ie/important-informationrelating-to-domestic-abuse-and-covid-19/. Accessed February 02, 2021.

42. European Centre for Disease Prevention and Control. Using face masks in the community first update: Effectiveness in reducing transmission of COVID-19. https://www.ecdc.europa. $\mathrm{eu} /$ sites/default/files/documents/covid-19-face-masks-communityfirst-update.pdf. Accessed February 15, 2021.

43. Health Service Executive, Ireland. Community Support during the Covid-19 Pandemic 2020. https://www2.hse.ie/services/ community-support-coronavirus/. Accessed February 02, 2021.

44. NI Direct. Coronavirus (COVID-19): practical support for individuals. https://www.nidirect.gov.uk/articles/coronavirus-covid19-practical-support-individuals. Accessed February 02, 2021.

45. Scottish Government. Coronavirus (COVID-19): Test and Protect 2020. https://www.gov.scot/publications/coronavirus-covid-19test-and-protect/pages/getting-support-if-you-need-it/. Accessed February 02, 2021.

46. Federal Ministry of Social Affairs, Health, Care and Consumer Protection, Austria. FAQ: tests and quarantine 2021. https://www. sozialministerium.at/Informationen-zum-Coronavirus/Coronavirus--Haeufig-gestellte-Fragen/FAQ--Testungen-und-Quarantaene.html. Accessed February 02, 2021.

47. The Connexion French News and Views. France COVID-19: self-isolation recommended but not forced. https://www. connexionfrance.com/French-news/France-Covid-19-Self-isolationrecommended-but-not-forced-as-new-home-visits-introduced. Accessed February 02, 2021.

48. United against COVID-19. If you cannot get essential supplies. https://covid19.govt.nz/everyday-life/shopping/if-you-cant-get-ess ential-supplies. Accessed February 02, 2021.

49. Government of Belgium. I'm looking for support. https://www.infocoronavirus.be/en/im-looking-for-support/. Accessed February 02, 2021.

50. Ministry of Social Affairs and Health, Finland. Individuals' and families' financial benefits and allowances during the coronavirus situation 2020. https://stm.fi/en/individuals-families-benefitsallowances-corona. Accessed February 02, 2021.

51. Government of Alberta. Isolation and quarantine requirements. https://www.alberta.ca/isolation.aspx. Accessed February 02, 2021.

52. Government of Ireland. Minister for Health welcomes additional funding of $€ 5.1$ million in homeless supports. https://www.gov.ie/ en/press-release/ad787-minister-for-health-welcomes-additionalfunding-of-51-million-in-homeless-supports/. Accessed February 02, 2021.

53. Government of the United Kingdom. NHS Test and Trace: how it works. https://www.gov.uk/guidance/nhs-test-and-trace-howit-works\#support-for-people-who-are-self-isolating. Accessed February 02, 2021.

54. Norwegian Institute of Public Health. Quarantine and Isolation. https://www.fhi.no/en/op/novel-coronavirus-facts-advice/facts-andgeneral-advice/quarantine-and-isolation/. Accessed February 02, 2021.

55. State Government of South Australia. Self-Isolation and Quarantine Arrangements COVID-19 Accommodation and Support Services. https://www.sahealth.sa.gov.au/wps/wcm/connect/public 
+content/sa+health+internet/resources/self-isolation+and+quaran tine+arrangements+covid-19+accommodation+and+support+ser vices. Accessed February 02, 2021.

56. Danish Health Authority. Self-isolation and voluntary out of home stays. https://www.sst.dk/en/English/Corona-eng/Symptoms_tes ted-positive-or-a-close-contact/Self-isolation-and-voluntary-out-ofhome-stays. Accessed February 02, 2021.

57. Chia ML, Him Chau DH, Lim KS, Yang Liu CW, Tan HK, Tan YR. Managing COVID-19 in a novel, rapidly deployable community isolation quarantine facility. Ann Intern Med. 2021;174:247-251. https://doi.org/10.7326/M20-4746

58. World Health Organisation. Coronavirus disease (COVID-19) advice for the public. https://www.who.int/emergencies/diseases/ novel-coronavirus-2019/advice-for-public. Accessed February 02, 2021.

59. National Institute for Public Health and the Environment, Netherlands. Coronavirus disease COVID-19. https://www.rivm. $\mathrm{nl} / \mathrm{en} /$ novel-coronavirus-covid-19/coronavirus-disease-covid-19. Accessed February 16, 2021.

60. Santé Publique France. COVID-19: prevention tools intended for healthcare professionals and the general public. https://www. santepubliquefrance.fr/dossiers/coronavirus-covid-19/coronavirusoutils-de-prevention-destines-aux-professionnels-de-sante-et-augrand-public. Accessed February 16, 2021.

61. Government of Canada. Download COVID Alert today. https:// www.canada.ca/en/public-health/services/diseases/coronavirusdisease-covid-19/covid-alert.html. Accessed February 16, 2021.

62. Government of the United Kingdom. Find out what support you can get if you're affected by coronavirus. https://www.gov.uk/findcoronavirus-support. Accessed February 16, 2021.

63. Australian Government. Department of Health. Head to Health. https://headtohealth.gov.au/covid-19-support/covid-19-support. Accessed February 16, 2021.

64. Santé Publique France. I have the signs of COVID-19 disease. https://www.santepubliquefrance.fr/maladies-et-traumatismes/mal adies-et-infections-respiratoires/infection-a-coronavirus/docume nts/depliant-flyer/j-ai-les-signes-de-la-maladie-du-covid-19-fichepatients. Accessed February 16, 2021.

65. Public Health Agency of Sweden. More about COVID-19. https:// www.folkhalsomyndigheten.se/the-public-health-agency-of-sweden/ communicable-disease-control/covid-19/covid-19-more-informa tion/. Accessed February 16, 2021.

66. Government of France. Restrictions and requirements in metropolitan France. https://www.gouvernement.fr/en/coronaviruscovid-19. Accessed February 16, 2021.

67. Scottish Government. Support for people affected by coronavirus (COVID-19). https://www.mygov.scot/coronavirus-covid-19/. Accessed February 16, 2021.

68. Government of France. TousAntiCovid application. https://www. gouvernement.fr/info-coronavirus/tousanticovid. Accessed February 02, 2021.

69. Public Health Wales. Coronavirus (COVID-19). https://phw.nhs. wales/topics/latest-information-on-novel-coronavirus-covid-19/. Accessed February 16, 2021.

70. Federal Office of Public Health, Switzerland. Coronavirus. https:// www.bag.admin.ch/bag/en/home/krankheiten/ausbrueche-epide mien-pandemien/aktuelle-ausbrueche-epidemien/novel-cov.html. Accessed February 16, 2021.

71. Directorate of Health, Iceland. What we advise. https://www.covid. is/english. Accessed February 16, 2021.

72. Public Health Agency, Northern Ireland. COVID-19: Information for the public. https://www.publichealth.hscni.net/covid-19coronavirus/covid-19-information-public. Accessed February 16, 2021.
73. Advice Northern Ireland. Benefits. https://www.adviceni.net/ coronavirus/benefits. Accessed February 02, 2021.

74. Government of Canada. Canada's COVID-19 Economic Response Plan. https://www.canada.ca/en/department-finance/economicresponse-plan.html. Accessed February 02, 2021.

75. Welsh Government. Contact tracing: support for workers and the self-employed. https:/gov.wales/contact-tracing-supportworkers-and-self-employed. Accessed February 16, 2021.

76. Government of the United Kingdom. Coronavirus (COVID-19): what to do if you're employed and cannot work. https://www.gov. uk/guidance/coronavirus-covid-19-what-to-do-if-youreemployed-and-cannot-work. Accessed February 02, 2021.

77. Federal Office of Public Health, Switzerland. Coronavirus: Isolation and quarantine. https://www.bag.admin.ch/bag/en/home/krank heiten/ausbrueche-epidemien-pandemien/aktuelle-ausbrueche-epi demien/novel-cov/isolation-und-quarantaene.html. Accessed February 16, 2021.

78. New Zealand Government. COVID-19 financial support tool. https://covid19.govt.nz/business-work-and-money/financial-supp ort/covid-19-financial-support-tool/. Accessed February 16, 2021.

79. Welsh Government. COVID-19 statutory sick pay enhancement scheme. https://gov.wales/covid-19-statutory-sick-pay-enhance ment-scheme. Accessed February 16, 2021.

80. Government of Ireland. Covid-19 Supports. https://enterprise.gov. ie/en/What-We-Do/Supports-for-SMEs/COVID-19-supports/\#fin ancial. Accessed February 02, 2021.

81. Government of Ireland. Enhanced IIIness Benefit for COVID-19 Information (multi-lingual). https://www.gov.ie/en/collection/ fe635-enhanced-illness-benefit-for-covid-19-information-multiling ual/. Accessed February 02, 2021.

82. Federal Ministry of Social Affairs, Health, Care and Consumer Protection, Austria. FAQ: work, education, economy. https://www. sozialministerium.at/Informationen-zum-Coronavirus/Coronavirus ---Haeufig-gestellte-Fragen/FAQ--Arbeit,-Bildung,-Wirtschaft.html. Accessed February 02, 2021.

83. Government of Iceland. Financial supports. https://www. government.is/government/covid-19/. Accessed February 16, 2021.

84. Norwegian Institute of Public Health. Follow-up of close contacts, quarantine and home isolation- advice for healthcare personnel. https://www.fhi.no/en/op/novel-coronavirus-facts-advice/testingand-follow-up/follow-up-close-contacts/. Accessed February 16, 2021.

85. The Social Insurance Institution. Infectious disease daily allowance. https://www.kela.fi/tartuntatauti. Accessed February 16, 2021.

86. Government of Belgium. Quarantine and self-isolation https:// www.info-coronavirus.be/en/quarantine-isolation/. Accessed February 02, 2021.

87. Welsh Government. Self-isolation support scheme. https://gov. wales/self-isolation-support-scheme. Accessed February 02, 2021.

88. Victorian Government. Test isolation and worker support payments. https://www.dhhs.vic.gov.au/employee-isolation-paymentcovid-19\#am-i-eligible-for-the-450-coronavirus-covid-19-test-isol ation-payment. Accessed February 16, 2021.

89. Ministry of Health, France. Test, alert, protect: elimination of the waiting day for employees who test positive for Covid-19 or symptomatic for Covid-19 while awaiting the result of their test. https://solidarites-sante.gouv.fr/actualites/presse/communiquesde-presse/article/tester-alerter-proteger-suppression-du-jour-decarence-pour-les-salarie-e-s. Accessed February 02, 2021.

90. The Danish Immigration Service. Coronavirus (COVID-19): Information for SIRI's users. https://www.nyidanmark.dk/en-GB/ Words-and-concepts/F\%C3\%A6lles/Corona-(COVID-19)-informa tion/Corona_COVID19_SIRI. Accessed February 16, 2021. 
91. Government of Belgium. COVID-19: The Consultative Committee has carried out a mid-term review and confirms existing rules. https://www.info-coronavirus.be/en/news/occ-08-01/. Accessed February 02, 2021.

92. State Government of Victoria. Isolation and quarantine - extra help and support. https://www.dhhs.vic.gov.au/quarantineisolation-extra-help-and-support-coronavirus-covid-19\#enforcingisolation. Accessed February 02, 2021.

93. Queensland Government. Self-isolation for Diagnosed Cases of COVID-19 Direction (No. 4). https://www.health.qld.gov.au/ system-governance/legislation/cho-public-health-directions-underexpanded-public-health-act-powers/self-isolation-for-diagnosedcases-of-covid-19-direction. Accessed February 02, 2021.

94. State Government of Northern Territories. Self-quarantine - noncompliance - Darwin. https://coronavirus.nt.gov.au/updates/items/ 2020-03-31-self-quarantine-non-compliance-darwin\#: :text=The \%20infringement\%20penalty\%20is\%20\%241\%2C099,isolation\%20 and\%20self-quarantine\%20arrangements. Accessed February 02, 2021.

95. Agency for a Quality Life. Penalties for non-compliance with quarantine and testing measures. https://covid.aviq.be/fr/testingparticuliers\#sanctions-non-respect-mesures-testing-quarantaine. Accessed February 02, 2021.

96. Government of Iceland. Violations of the Epidemiological Control Act and rules set in accordance with it, cf. Article 19 Epidemic Prevention Act no. 19/1997, due to pandemic COVID-19. https:// www.rikissaksoknari.is/fyrirmaeli/brot-gegn-sottvarnarlogum-ogreglum-settum-samkvaemt-theim-sbr.-19.-gr.-sottvarnalaga-nr.-191997-vegna-heimsfaraldurs-6. Accessed February 02, 2021.

97. New Zealand Legislation. Quarantine and Isolation. https:// legislation.govt.nz/regulation/public/2020/0241/latest/whole. html\#LMS401707. Accessed February 02, 2021.

98. NI Direct. Coronavirus (COVID-19) regulations: compliance and penalties. https://www.nidirect.gov.uk/articles/coronavirus-covid19-regulations-compliance-and-penalties. Accessed February 02, 2021.

99. Ministry of Health and Care Services, Norway. The Government is establishing clear quarantine and isolation rules. https://www. regjeringen.no/en/aktuelt/the-government-is-establishing-clear-qua rantine-and-isolation-rules/id2693647/. Accessed February 02, 2021.

100. Scottish Government. Coronavirus (COVID-19): international travel and quarantine. https:/www.gov.scot/publications/ coronavirus-covid-19-public-health-checks-at-borders/pages/selfisolation/\#: :text=If\%20you\%20fail\%20to\%20comply,contacted\% 20by\%20Public\%20Health\%20Scotland. Accessed February 02, 2021.

101. Immigration and Checkpoints Authority, Singapore. Stay Home Notice overview. https://safetravel.ica.gov.sg/health/shn. Accessed February 02, 2021.

102. Federal Office of Public Health, Switzerland. Noveau Coronavirus (French). https://www.bag.admin.ch/bag/en/home/suche. html\#fines. Accessed February 02, 2021.

103. Welsh Government. How to self-isolate when you travel to Wales: coronavirus (COVID-19). https://gov.wales/how-self-isolate-whenyou-travel-wales-coronavirus-covid-19\#section-50414. Accessed February 02, 2021.

104. Kavanagh AM, Mason KE, Bentley RJ, et al. Leave entitlements, time off work and the household financial impacts of quarantine compliance during an H1N1 outbreak. BMC Infect Dis. 2012;12:311. https://doi.org/10.1186/1471-2334-12-311

105. Kavanagh AM, Bentley RJ, Mason KE, et al. Sources, perceived usefulness and understanding of information disseminated to families who entered home quarantine during the H1N1 pandemic in Victoria, Australia: a cross-sectional study. BMC Infect Dis. 2011;11:2. https://doi.org/10.1186/1471-2334-11-2

106. Reed S, Palmer W. To solitude: Learning from other countries on how to improve compliance with self-isolation. Nuffield Trust comment. https://www.nuffieldtrust.org.uk/news-item/to-solitudelearning-from-other-countries-on-how-to-improve-compliance-withself-isolation-1. Accessed February 02, 2021.

107. Webster RK, Brooks SK, Smith LE, Woodland L, Wessely S, Rubin GJ. How to improve adherence with quarantine: rapid review of the evidence. Public Health. 2020;182:163-169.

108. Bavel JJV, Baicker K, Boggio PS, et al. Using social and behavioural science to support COVID-19 pandemic response. Nat Hum Behav. 2020;4:460-471.

109. Gelfand MJ, Harrington JR, Jackson JC. The strength of social norms across human groups. Perspect Psychol Sci. 2017;12:800-809.

110. National Academies of Sciences, Engineering, and Medicine. Evidence-Based Practice for Public Health Emergency Preparedness and Response. Washington, DC: The National Academies Press; 2020. https://doi.org/10.17226/25650

111. DiGiovanni C, Conley J, Chiu D, Zaborski J. Factors influencing compliance with quarantine in Toronto during the 2003 SARS outbreak. Biosecur Bioterror. 2004;2:265-272. https://doi.org/10. 1089/bsp.2004.2.265

112. Brooks SK, Webster RK, Smith LE, et al. The psychological impact of quarantine and how to reduce it: rapid review of the evidence. Lancet. 2020;395:912-920.

113. McVernon J, Mason K, Petrony S, et al. Recommendations for and compliance with social restrictions during implementation of school closures in the early phase of the influenza A (H1N1) 2009 outbreak in Melbourne, Australia. BMC Infect Dis. 2011;11:257.

114. The British Psychological Society. Encouraging self-isolation to prevent the spread of Covid-19. https://www.bps.org.uk/sites/ www.bps.org.uk/files/Policy/Policy\%20-\%20Files/Encouraging\%20 self-isolation\%20to\%20prevent\%20the\%20spread\%20of\%20Covid19.pdf. Accessed February 02, 2021.

115. Seale H, Dyer CEF, Abdi I, et al. Improving the impact of nonpharmaceutical interventions during COVID-19: examining the factors that influence engagement and the impact on individuals. BMC Infect Dis. 2020;20:607.

116. Sniehotta F. Towards a theory of intentional behaviour change: plans, planning, and self-regulation. $\mathrm{Br} J$ Health Psychol. 2021;14:261-273.

117. Lunn PD, Timmons S, Julienne $\mathrm{H}$, et al. Using decision aids to support self-isolation during the COVID-19 pandemic. Psychol Health. 2020;36:195-213. https://doi.org/10.1080/08870446. 2020.1849701

118. Economic and Social Research Institute. Deciding to self-isolate. Presentation to NPHET Behavioural Change Subgroup. Personal communication.

119. Timmons S, Barjaková M, Robertson D, Belton C, Lunn P. Public understanding and perceptions of the COVID-19 test-and-trace system. ESRI Survey and statistical report series Number 96. 2020.

How to cite this article: Cardwell K, O'Neill SM, Tyner B, et al. A rapid review of measures to support people in isolation or quarantine during the Covid-19 pandemic and the effectiveness of such measures. Rev Med Virol. 2021;e2244. https://doi.org/10.1002/rmv.2244 